\title{
Childhood Adrenocortical Tumours: a Review
}

\author{
Rosana Marques-Pereira, Luiz DeLacerda, Hadriano M. Lacerda, Edson Michalkiewicz, Fabiano Sandrini, Romolo Sandrini
}

Pediatric Endocrinology Unit, Department of Pediatrics, Clinical Hospital, Federal University of Parana; Curitiba PR, Brazil

Key words: adrenocortical tumours, TP53 mutations, children

Corresponding author: Romolo Sandrini, Unidade de Endocrinologia Pediátrica, R. Padre Camargo, 250 Curitiba - PR, Brazil 80060-240, e-mail: sandrini@ufpr.br

Submitted: 28 April 2006

Accepted: 20 May 2006

\begin{abstract}
Childhood adrenocortical tumour (ACT) is not a common disease, but in southern Brazil the prevalence is 15 times higher than in other parts of the world. One hundred and thirty-seven patients have been identified and followed by our group over the past four decades. Affected children are predominantly girls, with a female-to-male ratio of 3.5:1 in patients below 4 years of age. Virilization alone (51.6\%) or mixed with Cushing's syndrome (42.0\%) was the predominant clinical picture observed in these patients. Tumours are unilateral, affecting both glands equally. TP53 R337H germline mutations underlie most childhood ACTs in southern Brazil. Epidemiological data from our casuistic studies revealed that this mutation has 10\% penetrance for ACT. Surgery is the definitive treatment, and a complete resection should always be attempted. Although adjuvant chemotherapy has shown some encouraging results, its influence on overall outcome is small. The survival rate is directly correlated to tumour size; patients with small, completely excised tumours have survival rates close to $90 \%$, whereas in those patients with inoperable tumours and/or metastatic disease it is less than $10 \%$. In the group of patients with large, excisable tumours, half of them have an intermediate outcome. Recent molecular biology techniques and genomic approaches may help us to better understand the pathogenesis of ACT, the risk of developing a tumour when TP53 R337H is present, and to predict its outcome. An ongoing pilot study consisting of close monitoring of healthy carriers of the TP53 R337H mutation - siblings and first-degree relatives of known affected cases - aims at the early detection of ACTs and an improvement of the cure rate.
\end{abstract}

\section{Introduction}

Adrenocortical tumours (ACT) occur at all ages and have a bimodal distribution with peaks of incidence at around 5 years of age and in the $4^{\text {th }}$ and $5^{\text {th }}$ decades of life $[1,2]$. Childhood ACTs are rare, with the annual worldwide incidence around 0.34 per million children below the age of 15 $[1,3]$. In the United States, Surveillance Epidemiology and End Results (SEER) data from the National Cancer Institute show that only about $0.2 \%$ of all childhood malignancies are ACTs [4].
In southern Brazil (State of Paraná), the ACT incidence is 4.2 per million in the age range of $0-15$ years [5] with higher prevalence in 0 - 4-year-old girls (Fig. 1). Over the last 40 years, more than 137 ACT patients under 19 years of age have been admitted for treatment in the Pediatric Endocrinology Unit of the Department of Pediatrics in the Clinical Hospital of the Federal University of Paraná, in Curitiba, Brazil. This hospital is a tertiary referral centre for a population of approximately 16 million people, 5 million of whom are less than 15 years of age. It should be noted that at 


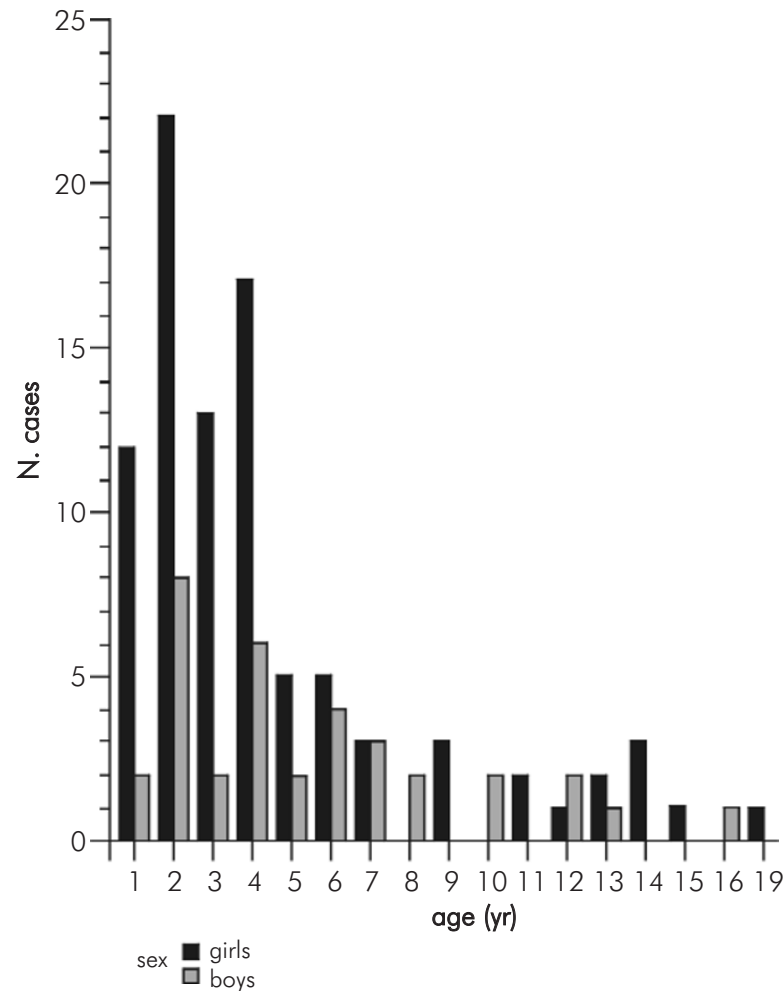

Fig. 1. Distribution of 125 cases of childhood adrenocortical tumour by age and gender

least 5 other hospitals in our state are referral centres for childhood malignancies. In the neighbouring State of São Paulo, Marigo et al. observed that childhood ACTs accounted for $2.9 \%$ of solid tumours registered at Santa Casa de Misericordia of São Paulo over a period of 15 years, whereas in the London Hospital for Sick Children, ACTs comprised only 0.8\% [6]. Later on, other groups in the State of São Paulo also reported a large series of ACTs in children and adolescents [7-10].

The population in these two Brazilian states are descendants of migrants from Portugal, Italy, Spain, Germany, Poland, Ukraine, Japan and Africa - countries where the incidence of ACTs is not increased - and a minority of the native population. The sporadic occurrence, absence of any clinical characteristics consistent with genetic disorders (i.e. Beckwith-Wiedemann and MEN1 syndromes, hemihypertrophy, congenital adrenal hyperplasia and Carney complex) or familial cancer history characteristic of Li-Fraumeni syndrome (LFS), is a common feature of the majority of Brazilian children with $\mathrm{ACTs}[5,8-11]$.

Childhood ACT is often the first indicator of a familial predisposition to cancer [12]. Typically, germline mutations in these families were mapped to the highly conserved DNA-binding domain of the TP53 gene (exons 5-8). However, some children who develop ACTs in the absence of familial cancer syndromes harbour germline mutations in other regions of TP53 [13]. Due to ACTs having a higher incidence in our state and the absence of mutations in exons 5-9 of TP53, all coding regions of the gene have been examined. A germline mutation, $\mathrm{R} 337 \mathrm{H}$ in exon 10 of TP53, was identified in 35 of 36 patients studied [1 1].

Because Paraná and São Paulo have extensive agricultural activities, it is tempting to speculate that environmental pollutants, such as pesticides, may pose a substantial health hazard and possibly contribute to adrenal tumorigenesis in individuals with the TP53 R337H mutations. Pesticides are widely used in Paraná without any safety guidelines. Interestingly, British investigators found an association between increased ACT incidence and pesticide use in North West England [14]. Supportive evidence is also forthcoming from Norway, where Kristensen et al. reported an almost 2-fold increase in the relative risk of cancer amongst 0 -4-year-old children whose parents were agricultural workers [15].

\section{Biological aspects of adrenocortical tumour}

Whether adrenocortical carcinomas develop from benign adenomas or are a separate disease remains to be fully determined. In our experience, all ACT cases clearly diagnosed as adenomas behaved benignly and were stage I disease (see Table 1). Those tumours associated with virilization (VS), Cushing's syndrome (CS), or mixed syndrome (MS - virilization and excess

Table 1. Staging criteria for childhood adrenocortical tumour (Sandrini et al. [5])

\begin{tabular}{ll}
\hline Stage & Description \\
\hline I & tumour totally excised; tumour vol. $<200 \mathrm{~cm}^{3}$, absence of metastasis, normal hormone levels after surgery \\
\hline II & $\begin{array}{l}\text { microscopic residual tumour; tumour }>200 \mathrm{~cm}^{3}, \text { tumour spillage during surgery or persistence } \\
\text { of abnormal hormone levels after surgery }\end{array}$ \\
\hline III & gross residual or inoperable tumour \\
\hline IV & distant metastasis \\
\hline
\end{tabular}


of cortisol and/or mineralocorticoids) were stage II tumours. Studies on tumour clonality aimed at distinguishing carcinomas from adenomas have shown disparate results $[16,17]$. At one extreme end of the spectrum, adrenocortical carcinomas are composed of a monoclonal population of cells, whereas at the other end, nodular hyperplasic adrenal tissue consists of a polyclonal cell population. In between are adenomas, where approximately half are monoclonal and half polyclonal and/or mixed [17]. However, in another study, almost all adenomas were monoclonal [16].

Several aspects of ACT formation are not well understood at the present time, in particular the reasons why some tumours are confined to certain dimensions and secrete exclusively one type of steroid, while others display more aggressive growth and metastasize and co-secrete various types of hormones.

In order to further understand adrenocortical tumorigenesis several mechanisms were identified from studies on rare genetic syndromes (reviewed in [18]), such as multiple endocrine neoplasia type 1 (Menin gene and locus 1 1q13), Carney complex (regulatory R1A subunit of protein kinase A - PRKARTA gene), Beckwith-Wiedemann (IGF-II and 11 p 15 changes) and McCune-Albright (GNAS 1 gene) syndromes, hemihypertrophy, congenital adrenal hyperplasia (CYP21 gene), glucocorticoid-remediable aldosteronism (hybrid gene formed by CYP11B1 and CYP11B2 genes), hereditary isolated glucocorticoid deficiency (MC2-R gene) and alterations of the TP53 gene.

Further complexity of ACT tumorigenesis was highlighted in a number of recent comparative genomic hybridization $(\mathrm{CGH})$ and microsatellite analysis studies aimed at detecting chromosomal alterations. These approaches identified alterations affecting various chromosomes and loci (either losses or gains of part or all of a chromosome) [17-21], both in adenomas and carcinomas. $\mathrm{CGH}$ techniques demonstrated alterations in 28\% [17] to 61\% [18] of adenomas. Sixty-two percent of adrenal carcinomas showed losses in several chromosomes [18, 20]. Also in carcinomas, studies using microsatellite markers revealed loss of heterozygosity $(\mathrm{LOH})$ /allelic imbalance in almost all cases, at $11 \mathrm{q} 13$ (100\%) and 2p 16 (92\%). Moreover, $\mathrm{LOH}$ at the $17 \mathrm{p} 13$ loci is highly specific to malignant tumours [18]. In 1999, our group reported a consistent gain in number of copies of chromosomal region 9q34 using CGH analysis [22].

More recently, gene expression profiling of ACT samples using DNA microarray technology has revealed previously unknown gene expression changes in $\mathrm{ACTS}$ [23-26]. In addition, Figueiredo et al. demonstrated the presence of high levels of DAX-1 transcripts and protein expression and amplification of SF-1 in ACTs [27].
However, these findings did not correlate with clinical manifestation of disease, such as tumour size, malignant or benign behaviour, sex and age.

It is known that the IGF system is important in foetal growth, and high expression of IGF-2, in concert with ACTH, occurs in human foetal adrenal development (reviewed in [28]). IGF-2 is also highly expressed in $85 \%$ of $A C T s$ [29-31]. In addition, other components of the IGF system are defective in ACTs; for example, over-expression of IGF binding protein 2 (IGFBP2) and IGF type-1 receptor (IGF1R) proteins. IGF type-2 receptor (IGF2R) loss of function by inactivating mutations located in the DNA coding region and $\mathrm{LOH}$ at the IGF2R loci were reported in ACTs [32, 33]. Knowledge of normal adrenal cortex development and linkage of ACTs to other genes, such as CDKN 1C [34], H19 [35], INHA [36], GATA-4 [37] and proteins such as angiopoietin, urotensin $\mathrm{II}$ and novH (reviewed in [28]), makes comprehension of the molecular events underlying adrenocortical tumorigenesis very intricate.

\section{TP53 mutations and tumorigenesis}

Recent progress has been achieved in the understanding of adrenocortical tumorigenesis by the mapping and identification of genes associated with hereditary adrenal gland tumours (reviewed in $[18,38])$. More generally, lesions either in the machinery that senses DNA damage or in the machinery that implements a response to DNA damage greatly alters the likelihood of cancer. Mutation in the tumour suppressor gene TP53 is a key mutational event in over half of all human cancers, and mutations in TP53 are the most frequently observed genetic change in cancer [39]. The high frequency with which p53 protein is functionally inactivated in human cancers indicates its pivotal role against the expansion of a population of mutated somatic cells. In many cases, TP53 itself is mutated or deleted $[40,41]$.

The p53 pathway responds to stresses that can disrupt the fidelity of DNA replication and cell division. Stress signals are transmitted to p53 proteins by post-translational modification. This results in activation of p53 protein as a transcription factor that initiates a programme of cell cycle arrest, cellular senescence or apoptosis. Which of these responses prevails seems to depend on cell type, cell environment, and other factors such as oncogene expression. Evidence indicates that p53 induces growth arrest after certain types of irreversible DNA damage; although alive, such cells are genetically dead as they cannot contribute to a daughter cell population and thus constitute no further neoplastic risk [42-48]. The transcriptional 
network of p53-responsive genes produces proteins that interact with a large number of other signal transduction pathways in cells and a number of positive and negative auto-regulatory feedback loops acting upon the TP53 response [49].

p53 is a 393 amino acid protein containing several functional domains: the activation domain 1 (AD1) within residues 1 to 42, the activation-domain 2 (AD2) within residues 43 to 63 , the proline-rich domain (PRD) within residues 64 to 91, the sequence-specific DNA-binding-domain (DBD) within residues 100 to 300, the nuclear localization signal within residues 316 to 325 , the tetramerization-domain (TD) within residues 334 to 356, and the C-terminal-basic-domain (BD) within residues 364 to 393 [39, 50-53].

\section{TP53 and paediatric ACT}

The majority of TP53 germline mutations in cancer are localized between exons 5 and 8, the highly conserved DNA-binding-domain of the gene, although mutations located in other regions have also been described. Highly penetrant TP53 germline mutations are identified in over $77 \%$ of families with Li-Fraumeni syndrome (LFS), an autosomal dominant inherited cancer syndrome characterized by the occurrence of a variety of cancers diagnosed at young ages [54-58]. In patients with LFS, ACT accounts for $3 \%$ of all tumours occurring at any age and for $10 \%$ of childhood ACTs [13]. Thus, TP53 mutations appear to increase ACTs predisposition in children. In North America and Europe, $50-80 \%$ of children with apparently sporadic ACTs carried TP53 germline mutations [13, 59].

Functional analysis of the TP53 germline mutation described in patients from Paraná showed that in contrast to TP53 R248W, the TP53 R337H mutant and wild type TP53 were able to suppress colony growth of $\mathrm{SaOs}-2$ cells lacking endogenous p53. In addition, in human H1299 lung carcinoma cells, which also lack endogenous p53, ectopically expressed TP53 R337H mutant was competent to induce apoptosis. Taken together these data indicate that the R337H mutant retains p53 activity at physiological conditions [11].

\section{TP53 mutation and paediatric ACT in southern Brazil}

TP53 R337H is present in $97 \%$ of all cases of children with ACT treated in the State of Paraná [11]. The same mutation was reported occurring at a prevalence of 75 and $77.7 \%$ by two independent groups of investigators in the neighbouring State of São Paulo $[8,9]$. The mutation was also identified in 5 of 37 and in 1 of 5 adult patients studied by the latter groups, respectively. Interestingly, adult patients who tested positive for the mutation were all young lage range 19 to 36 years).

Chompret et al. reported the same germline mutation in a 4-yr-old girl with sporadic ACT [60]. Varley et al. analysed a panel of 14 cases of sporadic childhood ACTs [13]. TP53 germline mutations were identified in over $80 \%$ and in one case the TP53 $\mathrm{R} 337 \mathrm{H}$ mutation was present in a tumour, with the complete loss of the wild type allele; however, they were unable to determine whether this mutation was inherited or acquired.

Recently, DiGiammarino et al. were able to expose subtle defects of the mutant protein while studying its behaviour, in vitro, under variations in $\mathrm{pH}$ and temperature [61]. From their study, it was shown that tetramer formation of the R337H p53 mutant becomes significantly less stable as $\mathrm{pH}$ increases toward the physiological range between 7 and 8 . A substantial fraction of mutant p53 R337H variants remain unfolded at $\mathrm{pH} 8$ and at $37^{\circ} \mathrm{C}$ (>70\% unfolded), whereas wildtype p53 is fully folded under the same conditions [61]. Previous to this study, Davison et al. using circular dichroism spectroscopy were also able to show the effects of temperature on the stability of the p53 mutant protein in families with LFS and Li-Fraumeni like syndrome with TP53 L344P and TP53 R337C mutations, respectively, located in the tetradimerization zone of TP53 [62]. The cause of the TP53 R337H mutation is presently unknown. The demonstration of different markers surrounding and within the mutated TP53 gene in various unrelated subjects strongly indicates that it is derived from diverse ancestors [1 1]. In contrast, Pinto et al. studied 22 patients ( 16 children and 6 adults) from the State of São Paulo and concluded that the TP53 R337H germline mutation arose from a single common ancestor [63].

Several lines of evidence show that the TP53 $\mathrm{R} 337 \mathrm{H}$ mutation is strongly related to $\mathrm{ACT}$ in children in southern Brazil: a) the families do not have a common ancestry; b) TP53 R337H is not a common polymorphism among southern Brazilians; c) the loss of heterozygosity with retention of the mutant allele in the tumour cells, and d) the mutant p53 protein is highly expressed in the ACTs $[11,64]$.

Over 927 individuals were tested for the TP53 R337H mutation, 232 from the non-carrier and 695 (including 40 probands) from the carrier parental line. In the carrier parental line, the mutation tested positive in 240 individuals (34.5\%) and in none of the non-carrier parental line [65]. In this group, fifty percent of the parents and grandparents evaluated carried the TP53 R337H mutation. Thus, there is no evidence of de novo mutation. All probands carried the mutation 
in the heterozygous state in the series of cases from Paraná. In the State of São Paulo, Latronico et al. described one patient who was homozygous for the mutation and whose parents both carried the mutation in a heterozygous state [8].

The estimated penetrance of ACT among carriers of the TP53 R337H mutation is 9.9\% $(95 \% \mathrm{Cl}, 8.7-11.1 \%)$ and it is greater in the 8 kindreds with multiple cases of ACT $(12.5 \%$; $95 \% \mathrm{Cl}, 10.2-14.6 \%)$ than in kindreds with a single case $(8.5 \% ; 95 \% \mathrm{Cl}, 7.3-9.7 \%)$ [65]. Varley et al. had already described TP53 mutations in 14 cases of childhood ACT with equally low cancer penetrance [13].

Although the penetrance of this mutation is low, close monitoring of children at risk of ACT is advisable in order to detect the presence of tumour as early as possible, thereby improving outcome. Relevant in this regard are the data of Pereira et al., where 65 children (siblings and first-degree relatives), 0.25 to 14.6 years of age and all carriers of the TP53 R337H mutation, have been followed for three consecutive years, on a clinical, laboratory and imaging basis. There is currently no evidence of ACT developing in these children. The aim of the study is to follow these individuals for as long as possible, in order to acquire more data to better define the penetrance of this mutation [66].

\section{Clinical features}

We have conducted a comprehensive review of 125 patients from 137 who attended our service between 1966 and December 2005.

Ninety patients were girls (72\%); median age of the entire group was 3.2 years, two thirds being aged 0-4 years (5 patients presented with an ACT at birth, Fig. 1). The ratio of girls to boys was 2.6:1 for this group and 3.5:1 in patients below 4 years. The mean time interval between the appearance of the first clinical signs and the diagnosis of disease was 11 months. None of the patients had conspicuous African, Brazilian, or Japanese ancestry.

Virilization alone was present in $51.2 \%$ of patients; virilization associated with Cushing's syndrome (CS) occurred in $42.4 \%$ of patients. One patient exhibited pure CS while another displayed isolated hypertension. Endocrine silent tumours comprised $4.8 \%$ of all patients. Percentages of occurrence of the main clinical signs (precocious puberty, clitoris or penis hypertrophy, coarse voice, hypertension, facial hyperaemia, weight gain, hirsutism, accelerated growth velocity, etc.) do not differ much from those in a group of 58 children studied by Sandrini et al. in 1997 [5].

Hypertension in the course of ACTs deserves special attention, especially in those patients with mixed syndromes (virilization and excess of cortisol and/or mineralocorticoids). Not infrequently it is severe enough to cause hypertensive encephalopathy with seizures. Aggressive therapy with ECA inhibitors and furosemide is routine in our service. After complete tumour removal hypertension does not abate rapidly; indeed, in some cases it persists for two to four weeks. The frequency of palpable abdominal mass is less than that reported in 1997, possibly due to increasing awareness, by paediatricians, of the possibility of adrenal tumour in young children with precocious puberty. Curiously, purple striae occurred in only 2 patients, although hypercortisolism was present in almost half of all patients. Vena cava invasion, extending to the right atrium, is usually associated with large and long-standing tumours; it is rarely present in the course of small tumours. Both glands were equally affected and concomitantly bilateral ACT has never been recorded. However, a 3.5-yr-old-girl who had a small tumour completely removed from the left adrenal presented with a tumour in the right gland 12 years later, with pulmonary metastasis and vena cava and right atrium invasion.

\section{Diagnosis}

At present, our routine hormonal profile for patients suspected of having ACT includes measurements of serum (8am, $11 \mathrm{pm}$ ) cortisol, testosterone, DHEA-S, androstenedione, 17-hydroxyprogesterone, aldosterone, and PRA.

Several different imaging techniques have been used to confirm the presence of tumour, for staging the disease and to help plan the surgical approach. Magnetic resonance (MR), computerized tomography (CT) and ultrasound (US) are used to confirm the presence of the tumour, to visualize invasion of close structures (liver, pancreas, kidney and diaphragm), metastasis and venous invasion. However, it should be stressed that depending on the equipment used, very small tumours may be missed when investigated by US alone. All newly diagnosed patients are scanned with CT to assess the level of metastasis, if any, in the lung and liver, as these are the most common sites of spread. Calcifications are frequent and can present either as small focal inclusions or extensive linear and amorphous deposits. Whole body fluoro-deoxyglucose positron-emission tomographic imaging (PET-SCAN) has been incorporated into the diagnostic procedures of ACT $[67,68]$.

\section{Treatment}

\section{Surgery}

Complete resection of tumour and local lymph nodes is the single most important procedure in 
successful treatment of ACT. En bloc resection, which may include the adjacent structures invaded by the tumour, is required in cases of large and invasive tumours. Due to the friability of the tumour, rupture of the capsule and tumour spillage can occur.

A hundred and twenty-three out of 125 patients have been operated on. In $86.2 \%$ of the cases the tumour was completely excised; in $10.6 \%$ the tumour was inoperable and in $3.2 \%$ only partial resection was performed.

Venous tumour invasion, especially of the vena cava, occurred in $19.6 \%$ of 92 patients in which it was carefully searched for. US, MR and cavography have been used to look for the presence of venous invasion. In cases where the tumour invades the right atrium the concurrence of a cardiovascular surgeon is mandatory. In such cases, extracorporeal circulation is recommended.

Surgical resection is also indicated for recurrent local disease or metastases. Multiple surgical interventions may be needed for recurrence, providing prolonged survival or even cure. One patient is free of disease 20 yrs after being operated on twice for tumour bed recurrence and once for hepatic metastases.

\section{Chemotherapy}

Chemotherapy has been used to treat metastatic ACT and for those cases of large inoperable or partially excised tumour and for recurrences. Despite the use of different protocols of chemotherapeutic agents, none has emerged that has been shown to be sufficiently effective to be widely adopted. Mitotane has been used since the 1960s, initially for adult patients [69]. It inhibits adrenocortical hormone biosynthesis and causes destruction of adrenal cells [70]. While low doses ( $<3 \mathrm{~g} /$ day) suppress steroid synthesis and regression of clinical signs, with higher doses ( $>3$ $\mathrm{g} /$ day) an adrenolytic effect is observed. It should be stressed that no correlation exists between suppressed steroid synthesis and tumour regression [71]. After years of enthusiasm for mitotane that peaked during the mid-1980s, subsequent large trials showed transient partial responses and no complete responses [70]. Despite objective response to mitotane observed in some patients, the survival rate was not significantly increased [72]. A clinical trial with mitotane conducted in our service included 10 consecutive children with stages II and III disease. Only a single patient with an inoperable tumour had a partial response, which permitted curative surgery; the patient has been disease-free for the last 16 yrs (unpublished data). Based on the experience of Berruti et al., who showed favourable results with a combination of mitotane with cisplatin, etoposide, and doxorubicin, we have adopted this scheme with a lower dose of mitotane $[66,73]$. Notwithstanding, low doses of mitotane produced side effects in a sizable proportion of patients, which included mainly nausea, vomiting, anorexia and mood changes. Despite the observation of complete remission of metastasis, the time of observation and the limited number of patients so far treated do not permit us to draw any firm conclusions [66]. Paediatric endocrinologists must have in mind the drawbacks derived from mitotane use and therefore patients should be followed closely. For instance, in order to avoid adrenal insufficiency double to triple doses of glucocorticoids and mineralocorticoids are needed.

\section{Prognosis}

Because of the heterogeneity and rarity of ACTs, prognostic factors have been difficult to establish. The diagnosis of ACT is made on the basis of gross and histological appearance of tissue obtained at surgery. Classification of ACT as having a malignant or benign potential based only on histopathology is difficult [5]. However, all 20 patients from our personal experience who have received the diagnosis of adenoma are still alive.

Due to difficulties in correlating the histopathological findings to ACT prognosis, clinical characteristics, laboratory profile, therapeutic approach and presence or absence of metastasis were evaluated in relation to outcome. A multivariate analysis showed that only tumour size was significantly associated with survival [5]. Subsequently, data of the International Pediatric Adrenocortical Tumor Registry (IPACTR), based on the evaluation of 254 patients, $43.4 \%$ of whom were from our service and $36.0 \%$ from other Brazilian centres, showed that tumour stage I (Table 1), virilization alone and age $0-<4$ years, were significantly related to greater probability of event-free survival $[5,74]$. On the other hand, incomplete tumour excision, capsule rupture during surgery and presence of intravenous thrombi were linked to a bad prognosis.

\section{Concluding remarks}

Several characterized TP53 polymorphisms showed altered regulation of $\mathrm{p} 53$ protein post-translational modifications, protein stability, nuclear localization and downstream signalling. Restoration of TP53 functions, in particular TP53-dependent apoptosis, is an attractive cancer therapeutic strategy. To exploit TP53-dependent apoptosis for the destruction of cancer cells, many studies have focused on strategies that preferentially 
activate TP53 to induce proapoptotic target genes. It is already known that there is great heterogeneity of p53 responsiveness among different tissues and during different stages of development. Thus, it appears that the regulation of p53 responsiveness plays an important role not only in cancer but also during embryogenesis and in normal tissue physiology. Therefore any individual who has poor p53 responsiveness to DNA damaging agents in internal tissues may be at a higher risk of developing cancer in these tissues. Two distinct prognostic groups of patients with $\mathrm{ACT}$ can be recognized: one with very poor prognosis (patients with metastatic disease or gross residual tumour) and one with a very good prognosis (patients with completely excised tumour of small size or adenoma histology). It would be of great interest to identify additional prognostic molecular markers within poor p53 responders more susceptible to $\mathrm{ACT}$ and possibly combine cancer-preventive therapies aimed at modulating TP53 activity to induce apoptosis in tumour cells. More importantly, future studies should delineate more complex genotypes associated with p53 mutations, novel elements in p53 cellular response and deregulated cellular processes in ACT. Indeed, recent molecular biology techniques and genomic approaches have identified key cellular processes fundamental for tumour development and progression.

Many questions remain unexplained in childhood ACTs: a) Why is only one adrenal gland affected? b) Could the hormonal milieu (oestriol during foetal growth and oestradiol in the first two years of life) underlie sex differences observed in ACT occurrence? c) Do cells from the adrenal cortex foetal zone escape apoptosis by the concerted action of several genes and gene products, making them susceptible to tumorigenesis? d) What endogenous and environmental factors determine tumour behaviour? e) Will prospective studies of patients and relatives with TP53 R337H mutation show whether, in the longer term, ACT can appear in the contra-lateral gland or play a role in other types of tumour?

\section{References}

1. Young JL Jr, Ries LG, Silverberg E, Horm JW and Miller RW. Cancer incidence, survival, and mortality for children younger than age 15 years. Cancer 1986; 58 (2 Suppl): 598-602.

2. Wooten MD and King DK. Adrenal cortical carcinoma. Epidemiology and treatment with mitotane and a review of the literature. Cancer 1993; 72: 3145-3155.

3. Stiller CA. International variations in the incidence of childhood carcinomas. Cancer Epidemiol Biomarkers Prev 1994; 3: 305-310.

4. Bernstein L and Gurney J. Cancer Incidence and Survival Among Children and Adolescents: United States SEER Program 19751995. Bethesda, MD. National Cancer Institute, SEER Program 1999; 139-147.

5. Sandrini R, Ribeiro RC and DeLacerda L. Childhood adrenocortical tumors. J Clin Endocrinol Metab 1997; 82: 2027-2031.
6. Marigo C, Mueller H and Davies J. Survey of cancer in children admitted to a Brazillian charity hospital. J Natl Cancer Inst 1969; 43: 1231-1240.

7. Waichenberg BL, Albergaria Pereira MA, Medonca BB, Latronico AC, Campos Carneiro P, Alves VA, Zerbini MC, Liberman B, Carlos Gomes $G$ and Kirschner MA. Adrenocortical carcinoma: clinical and laboratory observations. Cancer 2000; 88: 71 1-736.

8. Latronico AC, Pinto EM, Domenice S, Fragoso MC, Martin RM, Zerbini MC, Lucon AM and Mendonca BB. An inherited mutation outside the highly conserved DNA-binding domain of the p53 tumor suppressor protein in children and adults with sporadic adrenocortical tumors. J Clin Endocrinol Metab 2001; 86: 4970-4973.

9. Sandrini F, Villani DP, Tucci S, Moreira AC, de Castro M and Elias LL. Inheritance of R337H p53 gene mutation in children with sporadic adrenocortical tumor. Horm Metab Res 2005; 37: 231-235.

10. Dichtchekenian V, de Braganca Pereira CA, Kuperman H, Della Manna T, Damiani D, Ferreira Alves VA, Filho AL and Setian N. Adrenocortical carcinoma: prognostic indices based on clinical and immunohistochemical markers. J Pediatr Endocrinol Metab 2005; 18: 347-353.

11. Ribeiro RC, Sandrini F, Figueiredo B, Zambetti GP, Michalkiewicz E, Lafferty AR, DeLacerda L, Rabin M, Cadwell C, Sampaio G, Cat I, Stratakis CA and Sandrini R. An inherited p53 mutation that contributes in a tissue-specific manner to pediatric adrenal cortical carcinoma. Proc Natl Acad Sci U S A 2001; 98: 9330-9335.

12. Sameshima Y, Tsunematsu Y, Watanabe S, Tsukamoto T, Kawa-ha K, Hirata Y, Mizoguchi H, Sugimura T, Terada M and Yokota J. Detection of novel germ-line p53 mutations in diverse-cancer-prone families identified by selecting patients with childhood adrenocortical carcinoma. J Natl Cancer Inst 1992; 84: 703-707.

13. Varley JM, McGown G, Thorncroft M, James LA, Margison GP, Forster G, Evans DG, Harris M, Kelsey AM and Birch JM. Are there low-penetrance TP53 Alleles? evidence from childhood adrenocortical tumors. Am J Hum Genet 1999; 65: 995-1006.

14. Birch JM and Blair V. Increase in childhood carcinomas in Northwest England. Lancet 1988; 1: 833.

15. Kristensen P, Andersen A, Irgens LM, Bye AS and Sundheim L. Cancer in offspring of parents engaged in agricultural activities in Norway: incidence and risk factors in the farm environment. Int J Cancer 1996; 65: 39-50.

16. Beuschlein F, Reincke M, Karl M, Travis WD, Jaursch-Hancke C, Abdelhamid S, Chrousos GP and Allolio B. Clonal composition of human adrenocortical neoplasms. Cancer Res 1994; 54 : 4927-4932.

17. Gicquel C, Leblond-Francillard M, Bertagna X, Louvel A, Chapuis $Y$, Luton JP, Girard F and Le Bouc Y. Clonal analysis of human adrenocortical carcinomas and secreting adenomas. Clin Endocrinol (Oxf) 1994; 40: 465-477.

18. Libé R and Bertherat J. Molecular genetics of adrenocortical tumours, from familial to sporadic diseases. Eur J Endocrinol 2005; 153: 477-487.

19. Latronico AC and Chrousos GP. Extensive personal experience: adrenocortical tumors. J Clin Endocrinol Metab 1997; 82: 1317-1324

20. Wieneke JA, Thompson LD and Heffess CS. Adrenal cortical neoplasms in the pediatric population: a clinicopathologic and immunophenotypic analysis of 83 patients. Am J Surg Pathol 2003; 27: 867-881.

21. Koch CA, Pacak K and Chrousos GP. The molecular pathogenesis of hereditary and sporadic adrenocortical and adrenomedullary tumors. J Clin Endocrinol Metab 2002; 87: 5367-5384.

22. Figueiredo BC, Stratakis CA, Sandrini R, DeLacerda L, Pianovsky MA, Giatzakis C, Young HM and Haddad BR. Comparative genomic hybridization analysis of adrenocortical tumors of childhood. J Clin Endocrinol Metab 1999; 84: 1116-1121. 
23. Stojadinovic A, Brennan MF, Hoos A, Omeroglu A, Leung DH, Dudas ME, Nissan A, Cordon-Cardo C and Ghossein RA. Adrenocortical adenoma and carcinoma: histopathological and molecular comparative analysis. Mod Pathol 2003; 16: 742-751.

24. Giordano TJ, Thomas DG, Kuick R, Lizyness M, Misek DE, Smith AL, Sanders D, Aljundi RT, Gauger PG, Thompson NW, Taylor JM and Hanash SM. Distinct transcriptional profiles of adrenocortical tumors uncovered by DNA microarray analysis. Am J Pathol 2003; 162: 521-531.

25. de Fraipont F, El Atifi M, Cherradi N, Le Moigne G, Defaye G, Houlgatte R, Bertherat J, Bertagna X, Plouin PF, Baudin E, Berger F, Gicquel C, Chabre $O$ and Feige JJ. Gene expression profiling of human adrenocortical tumors using complementary deoxyribonucleic Acid microarrays identifies several candidate genes as markers of malignancy. J Clin Endocrinol Metab 2005; 90: 1819-1829.

26. Zhao J, Roth J, Bode-Lesniewska B, Pfaltz M, Heitz PU and Komminoth P. Combined comparative genomic hybridization and genomic microarray for detection of gene amplifications in pulmonary artery intimal sarcomas and adrenocortical tumors. Genes Chromosomes Cancer 2002; 34: 48-57.

27. Figueiredo BC, Cavalli LR, Pianovski MA, Lalli E, Sandrini $R$, Ribeiro RC, Zambetti G, DeLacerda L, Rodrigues GA and Haddad BR. Amplification of the steroidogenic factor 1 gene in childhood adrenocortical tumors. J Clin Endocrinol Metab 2005; 90: 615-619.

28. Coulter CL. Fetal adrenal development: insight gained from adrenal tumors. Trends Endocrinol Metab 2005; 16: 235-242.

29. Ilvesmaki V, Kahri Al, Miettinen PJ, Voutilainen R. Insulin-like growth factors (IGFs) and their receptors in adrenal tumors: high IGF-II expression in functional adrenocortical carcinomas. J Clin Endocrinol Metab 1993; 77: 852-858.

30. Mesiano S, Katz SL, Lee JY and Jaffe RB. Insulin-like growth factors augment steroid production and expression of steroidogenic enzymes in human fetal adrenal cortical cells: implications for adrenal androgen regulation. J Clin Endocrinol Metab 1997; 82: 1390-1396.

31. Sidhu S, Gicquel C, Bambach CP, Campbell P, Magarey C, Robinson BG and Delbridge LW. Clinical and molecular aspects of adrenocortical tumorigenesis. ANZ J Surg 2003; 73: 727-738.

32. Gicquel C, Bertagna X, Schneid H, Francillard-Leblond M, Luton $J P$, Girard F and Le Bouc Y. Rearrangements at the $11 \mathrm{p} 15$ locus and overexpression of insulin-like growth factor-ll gene in sporadic adrenocortical tumors. J Clin Endocrinol Metab 1994; 78: 1444-1453.

33. Leboulleux S, Gaston V, Boulle N, Le Bouc Y and Gicquel C. Loss of heterozygosity at the mannose 6-phosphate/insulin-like growth factor 2 receptor locus: a frequent but late event in adrenocortical tumorigenesis. Eur J Endocrinol 2001; 144: 163-168.

34. Barzon L, Chilosi M, Fallo F, Martignoni G, Montagna L, Palu G and Boscaro M. Molecular analysis of CDKN1C and TP53 in sporadic adrenal tumors. Eur J Endocrinol 2001; 145: 207-212.

35. Gao ZH, Suppola S, Liu J, Heikkila P, Janne J and Voutilainen R. Association of $\mathrm{H} 19$ promoter methylation with the expression of $\mathrm{H} 19$ and IGF-II genes in adrenocortical tumors. J Clin Endocrinol Metab 2002; 87: 1170-1176.

36. Longui CA, Lemos-Marini SH, Figueiredo B, Mendonca BB, Castro M, Liberatore R Jr., Watanabe C, Lancellotti CL, Rocha MN, Melo MB, Monte O, Calliari LE, Guerra-Junior G, Baptista MT, Sbragia-Neto L, Latronico AC, Moreira A, Tardelli AM, Nigri A, Taymans SE and Stratakis CA. Inhibin alpha-subunit (INHA) gene and locus changes in paediatric adrenocortical tumours from TP53 R337H mutation heterozygote carriers. J Med Genet 2004; 41 : 354-359.
37. Kiiveri S, Liu J, Arola J, Heikkila P, Kuulasmaa T, Lehtonen E, Voutilainen R and Heikinheimo M. Transcription factors GATA-6, SF-1, and cell proliferation in human adrenocortical tumors. Mol Cell Endocrinol 2005; 233: 47-56.

38. Sredni ST, Zerbini MC, Latorre MR and Alves VA. p53 as a prognostic factor in adrenocortical tumors of adults and children. Braz J Med Biol Res 2003; 36: 23-27.

39. Levine AJ. p53, the cellular gatekeeper for growth and division. Cell 1997; 88: 323-331.

40. Varley JM, McGown G, Thorncroft M, Santibanez-Koref MF, Kelsey AM, Tricker KJ, Evans DG and Birch JM. Germ-line mutations of TP53 in Li-Fraumeni families: an extended study of 39 families. Cancer Res 1997; 57: 3245-3252.

41. Varley JM, Thorncroft M, McGown G, Appleby J, Kelsey AM, Tricker KJ, Evans DG and Birch JM. A detailed study of loss of heterozygosity on chromosome 17 in tumours from Li-Fraumeni patients carrying a mutation to the TP53 gene. Oncogene 1997; 14: 865-871

42. Levine AJ, Finlay CA and Hinds PW. P53 is a tumor suppressor gene. Cell 2004; 116 (2 Suppl): S67-69, 61 p following S69.

43. Gottifredi V, Shieh SY and Prives C. Regulation of p53 after different forms of stress and at different cell cycle stages. Cold Spring Harb Symp Quant Biol 2000; 65: 483-488.

44. Allan LA and Fried M. p53-dependent apoptosis or growth arrest induced by different forms of radiation in U2OS cells: p21WAF1/CIP1 repression in UV induced apoptosis. Oncogene 1999; 18: 5403-5412.

45. Amsterdam A, Keren-Tal I and Aharoni D. Cross-talk between cAMP and p53-generated signals in induction of differentiation and apoptosis in steroidogenic granulosa cells. Steroids 1996; 61: 252-256.

46. Bunz F, Dutriaux A, Lengauer C, Waldman T, Zhou S, Brown JP, Sedivy JM, Kinzler KW and Vogelstein B. Requirement for p53 and p21 to sustain G2 arrest after DNA damage. Science 1998; 282: 1497-1501.

47. Kagawa S, Fujiwara T, Hizuta A, Yasuda T, Zhang WW, Roth JA and Tanaka N. p53 expression overcomes p21WAF1/CIP1-mediated G1 arrest and induces apoptosis in human cancer cells. Oncogene 1997; 15: 1903-1909.

48. Sidhu S, Martin E, Gicquel C, Melki J, Clark SJ, Campbell P, Magarey CJ, Schulte KM, Roher HD, Delbridge L and Robinson BG. Mutation and methylation analysis of TP53 in adrenal carcinogenesis. Eur J Surg Oncol 2005; 31: 549-554.

49. Harris SL and Levine AJ. The p53 pathway: positive and negative feedback loops. Oncogene 2005; 24: 2899-2908.

50. Wong KB, DeDecker BS, Freund SM, Proctor MR, Bycroft M and Fersht AR. Hot-spot mutants of p53 core domain evince characteristic local structural changes. Proc Natl Acad Sci U S A 1999; 96: 8438-8442.

51. Nicholls CD, McLure KG, Shields MA and Lee PW. Biogenesis of p53 involves cotranslational dimerization of monomers and posttranslational dimerization of dimers. Implications on the dominant negative effect. J Biol Chem 2002; 277: 12937-12945.

52. Mateu MG, Sanchez Del Pino MM and Fersht AR. Mechanism of folding and assembly of a small tetrameric protein domain from tumor suppressor p53. Nat Struct Biol 1999; 6: 191-198.

53. Lee AS, Galea C, DiGiammarino EL, Jun B, Murti G, Ribeiro RC, Zambetti G, Schultz CP and Kriwacki RW. Reversible amyloid formation by the p53 tetramerization domain and a cancer-associated mutant. J Mol Biol 2003; 327: 699-709.

54. Malkin D, Li FP, Strong LC, Fraumeni JF Jr., Nelson CE, Kim DH, Kassel J, Gryka MA, Bischoff FZ, Tainsky MA, et al. Germ line p53 mutations in a familial syndrome of breast cancer, sarcomas, and other neoplasms. Science 1990; 250: 1233-1238. 
55. Birch JM, Alston RD, McNally RJ, Evans DG, Kelsey AM, Harris $M$, Eden $O B$ and Varley JM. Relative frequency and morphology of cancers in carriers of germline TP53 mutations. Oncogene 2001; 20: 4621-4628.

56. Birch JM, Hartley AL, Tricker KJ, Prosser J, Condie A, Kelsey AM, Harris $\mathrm{M}$, Jones $\mathrm{PH}$, Binchy $\mathrm{A}$, Crowther $\mathrm{D}$, et al. Prevalence and diversity of constitutional mutations in the p53 gene among 21 Li-Fraumeni families. Cancer Res 1994; 54: 1298-1304.

57. Varley JM. Germline TP53 mutations and Li-Fraumeni syndrome. Hum Mutat 2003; 21: 313-320.

58. Varley J. TP53, hChk2, and the Li-Fraumeni syndrome. Methods Mol Biol 2003; 222: 117-129.

59. Wagner J, Portwine C, Rabin K, Leclerc JM, Narod SA and Malkin D. High frequency of germline p53 mutations in childhood adrenocortical cancer. J Natl Cancer Inst 1994; 86: 1707-1710.

60. Chompret A, Brugieres L, Ronsin M, Gardes M, Dessarps-Freichey F, Abel A, Hua D, Ligot L, Dondon MG, Bressac-de Paillerets B, Frebourg T, Lemerle J, Bonaiti-Pellie C and Feunteun J. P53 germline mutations in childhood cancers and cancer risk for carrier individuals. Br J Cancer 2000; 82: 1932-1937.

61. DiGiammarino EL, Lee AS, Cadwell C, Zhang W, Bothner B, Ribeiro RC, Zambetti $G$ and Kriwacki RW. A novel mechanism of tumorigenesis involving $\mathrm{pH}$-dependent destabilization of a mutant p53 tetramer. Nat Struct Biol 2002; 9: 12-16.

62. Davison TS, Yin P, Nie E, Kay C and Arrowsmith CH. Characterization of the oligomerization defects of two p53 mutants found in families with Li-Fraumeni and Li-Fraumeni-like syndrome. Oncogene 1998; 17: 651-656.

63. Pinto EM, Billerbeck AE, Villares MC, Domenice S, Mendonca $\mathrm{BB}$ and Latronico $\mathrm{AC}$. Founder effect for the highly prevalent R337H mutation of tumor suppressor p53 in Brazilian patients with adrenocortical tumors. Arq Bras Endocrinol Metabol 2004; 48: 647-650.

64. Hainaut P. Tumor-specific mutations in p53: the acid test. Nat Med 2002; 8: 21-23.

65. Figueiredo BC, Sandrini R, Zambetti GP, Pereira RM, Cheng C, Liu W, Lacerda L, Pianovski MA, Michalkiewicz E, Jenkins J, Rodriguez-Galindo C, Mastellaro MJ, Vianna S, Watanabe F, Sandrini F, Arram SB, Boffetta P and Ribeiro RC. Penetrance of adrenocortical tumours associated with the germline TP53 R337H mutation. J Med Genet 2006; 43: 91-96.

66. Pereira RM, Michalkiewicz E, Sandrini F, Figueiredo BC, Pianovski M, Franca SN, Boguszewski MC, Costa O, Cat I, Lacerda Filho L and Sandrini R. [Childhood adrenocortical tumors]. Arq Bras Endocrinol Metabol 2004; 48: 651-658.

67. Kreissig R, Amthaver H, Krude H, Steinmueller P, Stroszczynski C, Hosten N, Grueters A and Felix R. The use of FDG-PET and CT for the staging of adrenocortical carcinoma in children. Pediatr Radiol 2000; 30: 306

68. Ahmed M, Al-Sugair A, Alarifi A, Almahfouz A and Al-Sobhi S. Whole-body positron emission tomographic scanning in patients with adrenal cortical carcinoma: comparison with conventional imaging procedures. Clin Nucl Med 2003; 28: 494-497.

69. Bergenstal DM. Chemotherapy of adrenocortical cancer with 0 , p'DDD. Ann Int Med 1960; 53: 672-681.

70. Luton JP, Cerdas S, Billaud L, Thomas G, Guilhaume B, Bertagna X, Laudat MH, Louvel A, Chapuis Y, Blondeau P, et al. Clinical features of adrenocortical carcinoma, prognostic factors, and the effect of mitotane therapy. N Engl J Med 1990; 322: 1195-1201.

71. Kasperlik-Zaluska AA. Clinical results of the use of mitotane for adrenocortical carcinoma. Braz J Med Biol Res 2000; 33: $1191-1196$

72. Ahlman H, Khorram-Manesh A, Jansson S, Wangberg B, Nilsson $O$, Jacobsson CE and Lindstedt S. Cytotoxic treatment of adrenocortical carcinoma. World J Surg 2001; 25: 927-933.
73. Berruti A, Terzolo M, Pia A, Angeli A and Dogliotti L. Mitotane associated with etoposide, doxorubicin, and cisplatin in the treatment of advanced adrenocortical carcinoma. Italian Group for the Study of Adrenal Cancer. Cancer 1998; 83: 2194-2200.

74. Michalkiewicz E, Sandrini R, Figueiredo B, Miranda EC, Caran E, Oliveira-Filho AG, Marques R, Pianovski MA, Lacerda L, Cristofani LM, Jenkins J, Rodriguez-Galindo C and Ribeiro RC. Clinical and outcome characteristics of children with adrenocortical tumors: a report from the International Pediatric Adrenocortical Tumor Registry. J Clin Oncol 2004; 22: 838-845. 